\title{
Prevalence, population dynamics and host preferences of Culicoides spp. (Diptera: Ceratopogonidae) of livestock in Marathwada region of Maharashtra State*
}

\author{
B. W. Narladkar ${ }^{1}$ and P. R. Shivpuje ${ }^{2}$
}

1. Department of Veterinary Parasitology, College of Veterinary and Animal Sciences, Maharashtra Animal \& Fishery Sciences University, Parbhani, Maharashtra, India; 2. Marathwada Agricultural University, Parbhani, Maharashtra, India.

Corresponding author: B. W. Narladkar, e-mail: babanar47@gmail.com, PRS: pralhadshivpuje@rediffmail.com

Received: 24-05-2014, Revised: 31-07-2014, Accepted: 04-08-2014, Published online: 27-09-2014

doi: 10.14202/vetworld.2014.717-726. How to cite this article: Narladkar BW, Shivpuje PR (2014) Prevalence, population dynamics and host preferences of Culicoides spp. (Diptera: Ceratopogonidae) of livestock in Marathwada region of Maharashtra State, Veterinary World 7(9): 717-726.

\begin{abstract}
Aim: The present study is a part of a research project on integrated pest management of livestock pests with reference to Culicoides spp. Study of prevalence, population dynamics and host preferences are the important benchmarks essential for chalking out the strategies of integrated pest management of Culicoides, thus the study was aimed.

Materials and Methods: Light trap collections of Culicoides midges and other tiny flies from animal shed from seventeen centers representing entire Maharashtra state were conducted. Similarly, year round collections from host sheds were envisaged to work out host preferences and population dynamics of Culicoides spp. locally prevalent. Multiple regression analysis was employed to define the environmental predictors responsible for ups and downs during different seasons occurring in the geographic region of the present study.
\end{abstract}

Results: Study revealed the prevalence of Culicoides spp., Phlebotomus spp. and Simulium spp. Simultaneous study undertaken by the aid of hand net, collections of fly species from Marathwada region of Maharashtra state yielded additionally, Tabanus spp., Pangonia spp., mosquitoes and other cyclorrhaphan flies. Some of the species are vectors of livestock diseases hence map of the distribution of these pest species is for to reckon risk areas. Population dynamics study on Culicoides spp. in Marathwada region indicated that, (a) Culicoides population were persistent throughout the year; (b) Two peaks of population, one in the monsoon (August-September) and another minor peak occurred during post monsoon/beginning of winter (November) of the year. Drastic reduction in the population occurred during the month of May, which is the hottest month in the year. Culicoides collections from the sheds of different host species indicated the preferences for feeding in the ascending order of preference as cattle, sheep, buffaloes and then goats.

Conclusion: Prevalence of Culicoides schultzei, Culicoides peregrinus and Culicoides actoni was occurred in the Marathwada region of Maharashtra along with other haematophagus flies. Seasonal population dynamic studies depicted two peaks in the Culicoides population, and peak population observed during the monsoon season. Study on the parameters is essential for the preparation of prediction models and forecasting.

Keywords: Culicoides spp., host preferences, livestock, Marathwada, population dynamics.

\section{Introduction}

Culicoides (Diptera: Ceratopogonidae) are commonly known as biting/bloodsucking midges or gnats $(1-3 \mathrm{~mm})$ presenting a huge diversity with more than 1300 species described worldwide [1,2] of which some $96 \%$ are hematophagous. These midges are of great concern because they transmit bluetongue (BT) [3,4], African horse sickness virus (AHSV), epizootic hemorrhagic disease virus (EHDV), equine encephalitis virus (EEV), akabane virus, bovine ephemeral fever virus [5] and Schmallenberg disease in 2011 [6,7]. Biting midges are also a source of nuisance through the bites of females. Their presence can, therefore, hinder the economic development of some regions, hampering agricultural and forestry activities, as well as

Copyright: The authors. This article is an open access article licensed under the terms of the Creative Commons Attributin License (http:// creative commons.org/licenses/by/2.0) which permits unrestricted use, distribution and reproduction in any medium, provided the work is properly cited. tourism development [8]. BT is a viral disease causing morbidity and mortality in sheep, cattle and wild ruminants, including deer, sambar and bluebull. BT is endemic in many parts of India and its outbreak in TamilNadu during the monsoon season of 19971998 caused the death of 300,000 sheep and goats and occurrence of this disease in many parts of India over the last few decades has affected millions of sheep and goats and other livestock [9]. Although the importance of autochthonous Culicoides species in the dissemination of BT virus (BTV) and SV is now generally recognized [10], many aspects of the ecology of native Culicoides species are still not fully understood, and there is a lack of information concerning to their dispersal, vectorial capacity, feeding and host-seeking behavior, mating, resting and oviposition are important for understanding disease

\footnotetext{
* Research carried out under Department of Biotechnology, Ministry of Science \& Technology, Government of India, New Delhi Funded Research Project on IPM for Livestock.
} 
transmission, longitudinal entomological intervention and for control, so that the transmission of the disease during outbreak of BT can be stopped $[9,10]$. The elucidation of the field biology of Culicoides midges is instrumental for the implementation of control measures and disease risk analysis. Though BT disease in several states of India is endemic viz. Tamil Nadu, Andhra Pradesh, Karnataka, Maharashtra, Gujarat, Rajasthan, Haryana, Himachal Pradesh and Jammu and Kashmir, until then the knowledge of Culicoides spp. as a vector of BT is poorly known in many parts of India [9]. Considering these facts, research on various aspects of epidemiology, biology, bio-control agents and integrated pest management of Culicoides spp. prevalent in parts of India is of utmost important.

In 1994, during a workshop on "Research and Extension needs for Integrated Pest Management (IPM) for arthropods of Veterinary importance" conducted at Lincoln USA, first-time needs of IPM against major pests of livestock were documented and defined [11]. As a result direct losses caused by livestock pests to the certain extent were documented. Realizing the importance and timely need of IPM against livestock pests including Culicoides spp., authors conducted detailed research under DBT financed project entitled as development of IPM module against important dipteran pests of livestock with reference to Culicoides midges (Diptera: Ceratopogonidae), on various aspects, including species prevalent, population dynamics and host preferences of Culicoides spp. in Maharashtra state and is reported in the present paper. It is wellknown fact that for undertaking IPM against any pest, sound knowledge of population dynamics and prevalence of pest in a particular geographic area is a must. Thus, during the project work survey across the state were undertaken, for recording the prevalence of Culicoides spp. However during light trap collection several other flies were also collected. All such fly species acting as pests of livestock and discharging the role of potent vector are also reported.

\section{Materials and Methods}

\section{Survey work of Culicoides and other fly species in the Maharashtra state}

For the survey of Culicoides along with other fly species biting to the livestock, collection work from 16 representative sites were undertaken in the state of Maharashtra. Geographically and politically Maharashtra state is divided into four regions viz. Marathwada, Vidarbha, Konkan and Western Maharashtra. In each region, four places (Four sites representing four regions of the state) were selected for collection. Such 16 collection locations + one location as Parbhani where project work was undertaken. Collection work was completed within 40 days time by provision of special vehicle (Figures 1 and 2) carrying light trap with high power battery as energy source when electric supply was discontinued. Use of light

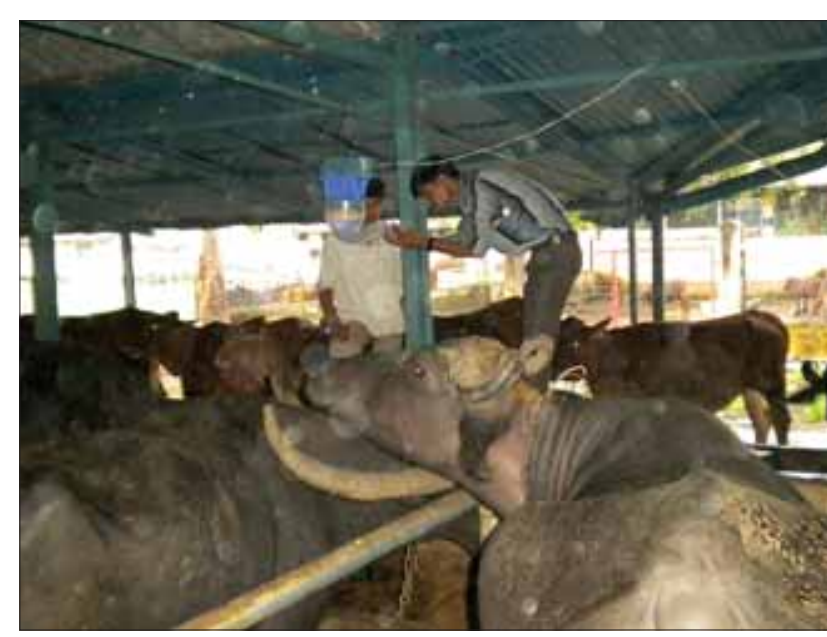

Figure-1: Light tap collections of Culicoides spp. and other flies in buffalo shed.

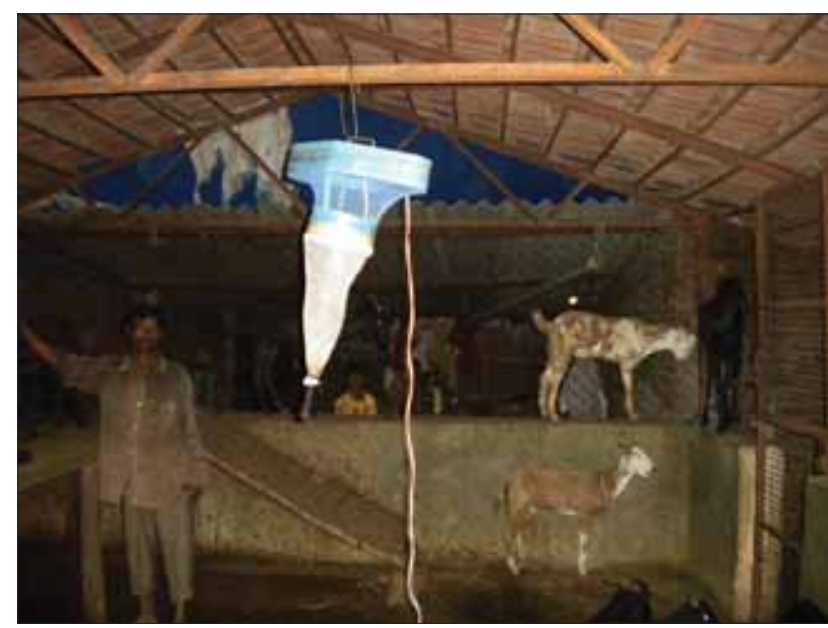

Figure-2: Light tap collections of Culicoides spp. and other flies in goat shed.

traps is considered as the standard method [12,13] for collection of midges. Collection work at each place was undertaken at dawn and dusk time by operating light trap for $10 \mathrm{~min}$. Collected Culicoides were preserved in labeled vials containing $70 \%$ alcohol glycerin, brought to Parasitology Department. Flies in the vials were subjected to further studies under zoom stereoscopic microscope and were categorized into different fly species along with Culicoides spp. Collected flies of different species including Culicoides spp., which were primarily identified under zoom stereoscope by employing the keys [14,15], were also sent in absolute alcohol to NBAII, Bangalore for molecular identification and DNA bar coding.

\section{Preparation of map of the Maharashtra state depict- ing areas of prevalence of Culicoides and other fly species}

Data on identification of fly species were tabulated, and predominance/abundance of the different Culicoides species at 17 locations was depicted in the political map of Maharashtra state (Figure-3). Identification of Culicoides and other fly species were further confirmed at NBAII, Bangalore. 


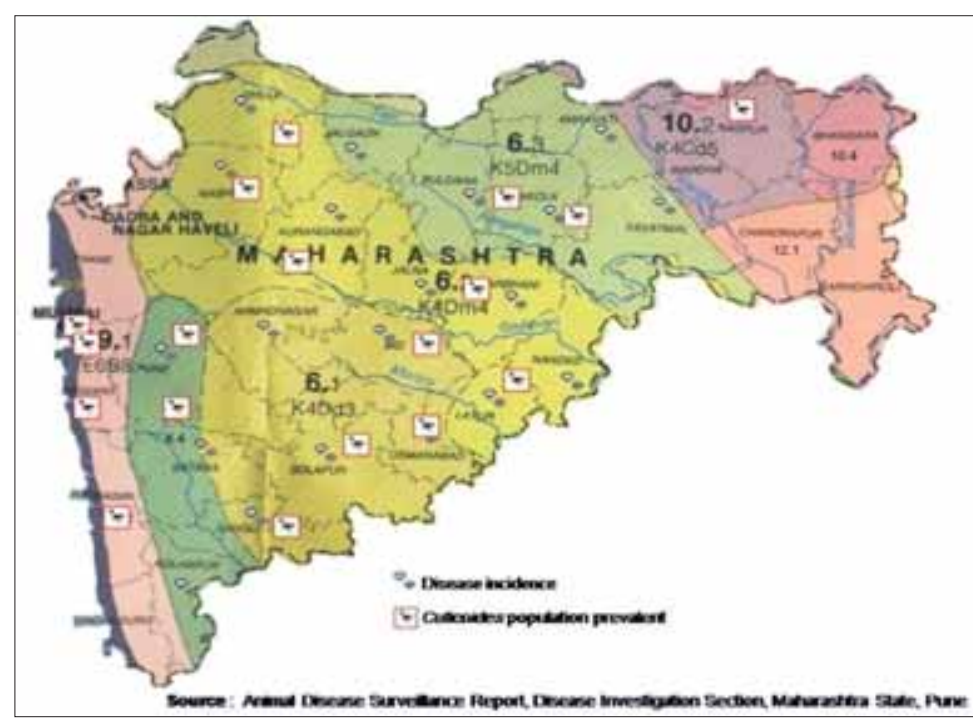

Figure-3: Map depicting prevalence of Culicoides spp. in Maharashtra state.

\section{Reporting of fly species from Parbhani and other parts of Marathwada region}

Simultaneous studies from Marathwada region were envisaged by collecting large sized flies with the use of hand nets from animal sheds belonging to Veterinary College and animal units of Agricultural University Parbhani. Additional collections were also made from animal sheds belonging to many villages from Marathwada region (places wherefrom farmers have frequently reported the nuisance/abundance of flies). Collected flies were identified in the laboratory, further identified at NBAII, Bangalore and are also reported here.

\section{Seasonal population dynamics of Culicoides and its correlation with meteorological data}

The Culicoides collection were undertaken with the help insect light trap for $5 \mathrm{~min}$ in the cattle shed at morning $7.00 \mathrm{am}$, thrice in a week for twelve months of a calendar year 2010. Insect light trap having ultra violet light were found to be best among the different colored light traps and therefore used for all the collections. The Culicoides collected in the trap were examined under zoom stereoscopic microscope, separated according to the species and counted. The environmental data were gathered from meteorology observatory of grade B belonging to Matathwada Agril University Parbhani. Multiple regression analysis was applied to the data and correlation was worked out between year round collections of Culicoides spp. and meteorological data.

\section{Host preferences of Culicoides spp}

Collection work of the Culicoides were undertaken from the different sheds in which various species of host animals such as cattle, buffaloes, sheep and goats are maintained. The collections from these sheds were undertaken with insect light trap, with an equal number of collections by allotting $5 \mathrm{~min}$ time for each collection, were examined under zoom stereoscopic microscope, separated according to the species and counted.

\section{Results and Discussion}

\section{Identification of Culicoides species}

Culicoides species collected from 17 locations from Maharashtra state revealed the presence of three species namely [16]:

1. Culicoides peregrinus Kieffer, 1910

2. Culicoides schultzei Enderlein, 1908

3. Culicoides actoni Smith, 1929.

All these three species of Culicoides previously recorded from Marathwada region of the state, are found distributed in all the regions of Maharashtra state [17]. Besides Culicoides similar sized fly species such as Simulium and Phlebotomus etc., were also confirmed as detailed in Table-1. The survey of fly species of livestock pests was probably undertaken for the first time in Maharashtra state.

\section{Survey work of Culicoides and other fly species in the Maharashtra state}

Perusal of Table-1, indicates that three Culicoides species, one Sergentomyia(Phlebotomus), one Simulium, one Aedes mosquitoes, two species of Musca house flies and another scavenger flies were prevalent in the state. The molecular identification has to be confirmed on the basis of morphology for getting accession number. Until now, three Culicoides species, Sergentomyia punjabensis, Simulium truncatum, Aedes aegypti mosquitoes, two species of house flies as Musca formosana and Musca domestica have been confirmed morphologically. The fly marked as Sergentomyia contained mixed population of $S$. punjabensis and Phlebotomus spp. Other flies yet to be morphologically confirmed. All confirmed species from genus Culicoides, Phlebotomus, Simulium, Aedes and Musca are potent vectors (mechanical/biological) of one or the other diseases. 


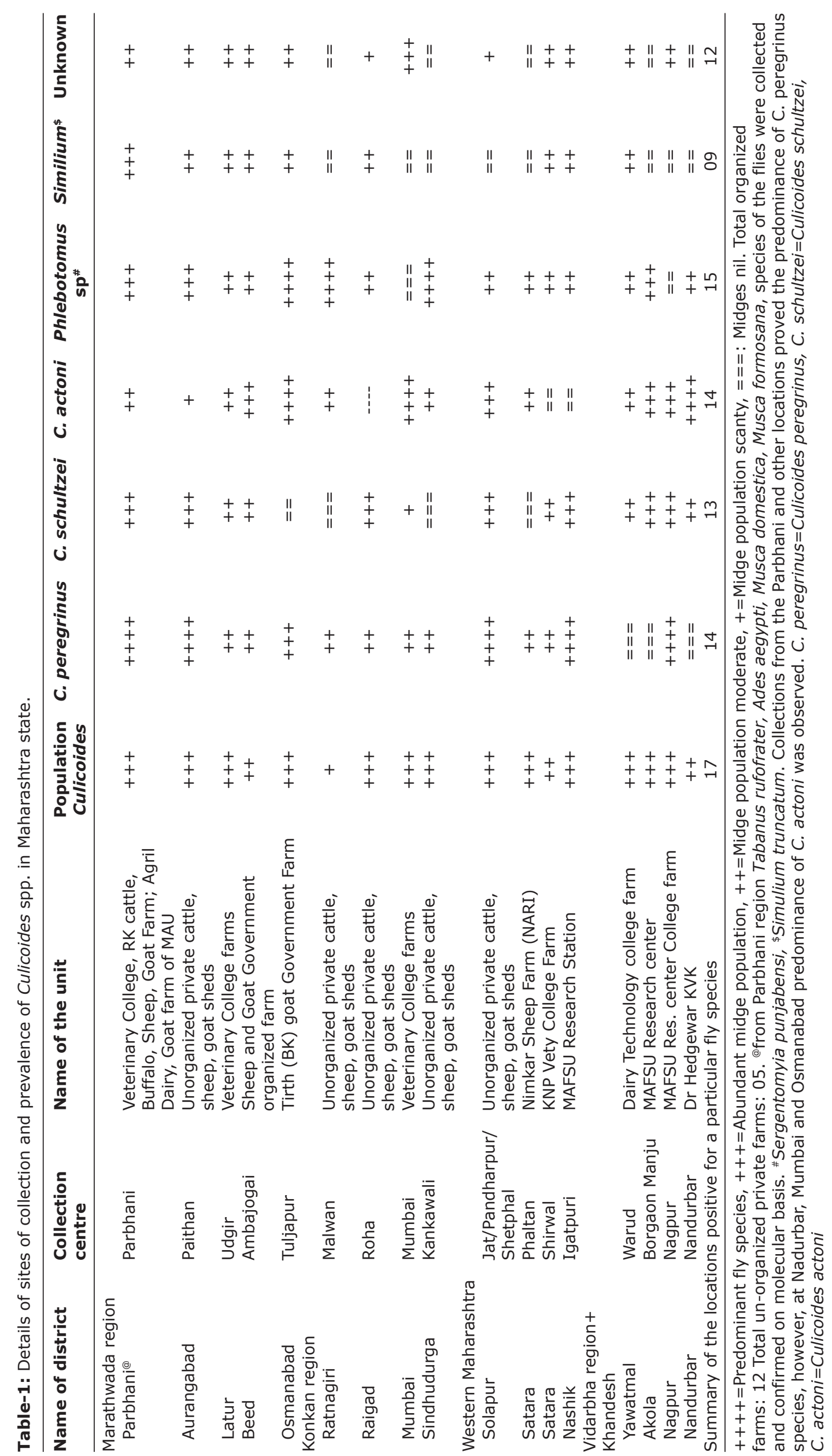




\section{Importance of studying geographic distribution and} plotting of map

The transmission of BTV by the midges involves complicated process, governed by several factors $[18,19]$. Mere presence of vector and host does not necessarily mean the outbreak of BT disease. However, data of BT disease for 1985-2004 from Maharashtra state, indicates that disease has occurred in the past in almost all districts (except few coastal and some Vidarbha peripheral districts) during 1 or the other year. After correlating the data of BT disease for 1989-2004 and presence of Culicoides recorded in the present project across the state, it is abundantly clear that there exist a definite correlation between these two variants. Thus, prepared map depicting the prevalence of any fly (vector) in a particular geographic area is an important benchmark for (a) Deciding the risk areas vulnerable to diseases vectored by these fly species, (b) It helps in chalking out the strategic plan for control measures against vectors and can be considered as prediction-map useful to policy makers, (c) To undertake IPM program against any fly/pest species sound knowledge of epidemiology is prerequisite. The present study will certainly of immense use while formulating IPM module against these flies, and (d) This map of distribution of Culicoides species along with other vector species will definitely help to target not only vectors, but also for undertaking management of many vector borne livestock diseases. Probably, this is the first attempt in the country.

\section{Species of Culicoides in India}

Udupa [20] and Bhoyar et al. [21] did the work on various aspects of species at Chennai and Bidar, respectively. In India citing the works of Kieffer (1910, 1911, 1913) [22-26], Sen and Fletcher [27], enumerated 28 Culicoides species in India. Of these 28 species, most of them belonged to Calcutta, whereas one species Culicoides pattoni was collected from Calcutta, Assam/Puri. Quoting the work of Patel [23], Sen and Fletcher [27] also reported the species of Culicoides oxystoma from Bombay Veterinary College. Sen and Dasgupta [15] reported 31 Culicoides species and one variety, while Dasgupta [28-31] added few more species from Calcutta. Of these 31 species, $C$. pattoni and Culicoides indianus were reported from Coimbatore and Dharwar [15], Culicoides alatus from Pune [32], and three species, i.e., Culicoides fulves, Culicoides clavipalpis and Culicoides similis were reported from Madras [33]. In all from India total around 50 species and one variety are documented. These include C. actoni, Culicoides autumnalis, C. alatus, Culicoides albipennis, Culicoides anophelis, Culicoides bimaculicosta, Culicoides brevimanus, Culicoides certus, C. clavipalpis, Culicoides candidus, Culicoides daleki, Culicoides dumdumi, Culicoides distinctus, Culicoides definitus, Culicoides fortis, C. fulvus, Culicoides fulvithorax, Culicoides himalayae, Culicoides innoxius, Culicoides iniquus, C. indianus, Culicoides imperceptus, Culicoides inexploratus, Culicoides kamrupi, Culicoides macrostoma, Culicoides macfiei, Culicoides molestus, Culicoides minutus, Culicoides magnificus, Culicoides nitidulus, C. oxystoma, Culicoides orientalis, Culicoides odiosus, Culicoides opacus, C. peregrinus, Culicoides palpifer, Culicoides paivai, Culicoides pictiventris, Culicoides pseudoturgidus, Culicoides paralini, C. pattoni, Culicoides quadrilobatus, Culicoides raripalpis, C. schultzei, Culicoides shortti, C. similis, Culicoides setiger, Culicoides scapularis, Culicoides superfulvus and Culicoides turgidus and one variety as $C$. peregrinus var. assamensis. From Darjeeling region of India Wirth et al. [34] reported Culicoides spinulosus and Culicoides majorinus species. In 2006 [9], reported the detailed fauna of Indian Culicoides species and their likely role in BT disease transmission.

Other flies reported from Marathwada region of Maharashtra as detailed in Table-2.

\section{Species of Tabanids}

Tabanus rufofrater, Heamatopota and Pagonia flies are observed in the Parbhani region of Maharashtra. T. rufofrater has been confirmed on the basis of molecular analysis at NBAII Bangalore [35]. However other two species not confirmed to species level.

The family Tabanidae belongs to the suborder Brachycera and infraorder Tabanomorpha. Members of this family are commonly known as horse flies (Tabanus), deer flies (Chrysops), and clegs (Haematopota). These flies are facultative hematophagous ectoparasites, thus important from medical and veterinary point of view. They are efficient mechanical carriers of various diseases and responsible for transmission of more than 25 animal diseases. Recently Veer [36] reviewed studies carried out on the family Tabanidae from the Indian sub-region with a few additions to Indian fauna by Mitra et al. [37], bringing the number of known species/subspecies from India to 244 species/subspecies under 15 genera. Veterinary important tabanids are enlisted from the web-based information entitled as checklist of Indian horse and deer flies (insecta: diptera:tabanidae) by Mitra (Zoological Survey of India, New Alipore, Kolkata-700 053) and Sharma (Zoological Survey of India, Central Zone Regional Centre, Jabalpur-482 002).

Table-2: Fly species reported from Parbhani and other parts of Marathwada region.

\begin{tabular}{ll}
\hline Name of the place & Fly species reported \\
\hline Parbhani and adjoining & Tabanus rufofrater, Ades \\
areas, Sillod (District & aegypti, Musca domestica, \\
Aurangabad), Udgir & Musca formosana, \\
(District Latur) & Pangonia* spp \\
Parbhani and adjoining & \\
areas (Village Kupta), & \\
Beed and adjoining areas & \\
*Identified under zoom stereoscope on the basis of \\
morphology, proboscis, wing characteristics etc.
\end{tabular}




\section{Population dynamics of Culicoides spp}

Variation in the population occurred during all the three seasons. However, it is clear from the data in Table-3, that (a) Culicoides population were persistent throughout the year; (b) two peaks of population, one in the monsoon (August-September) and another minor peak occurred during post monsoon/ beginning of winter (November) of the year. Drastic reduction in the population occurred during the month of May, which is the hottest month in the year. In view of the climatological data, the observations in the present project were most expected, because the climatic parameters in the monsoon season are favorable for the growth of not only Culicoides, but other various species of insects having aquatic larval and pupal stages. Second the climatic conditions were mostly favorable for growth of bacterial flora and other biological fauna in stagnant water/rain water lodged bodies. These factors contribute to increasing in population of Culicoides larvae that consumes bacterial flora as a food for growth and survival. Perhaps this could be a possible reason that, monsoon season happens to be a season of Culicoides peak population. Contrary to this, in the region mercury swings between 35 and $45^{\circ} \mathrm{C}$ during the summer season with very low relative humidity $(\mathrm{RH})$ creating arid environment. Overall bacterial population, biological fauna, etc., are destroyed due to lack of moisture and low RH. This explains the reduction in Culicoides population during the summer season. The temperature during the winter season oscillates between 10 and $25^{\circ} \mathrm{C}$, critically speaking cannot be regarded as a typical winter season observed in Europe and some other continents of the world. Similarly, winter season in this area is followed by monsoon and can be considered as post-monsoon season during which scattered rainfall and availability of breeding places with favorable/requisite temperature and $\mathrm{RH}$ range, makes the Culicoides midge survival possible and it reflects in the occurrence of second minor peak. Of all the abiotic factors monitored, the average temperature, $\mathrm{RH}$ and wind speed have a major role in the variability of the total number of Culicoides. Dynamics of Culicoides population is positively correlated with a minimum temperature $\left(11.5-16^{\circ} \mathrm{C}\right)$ [38]. Peaks of abundance of C. oxystoma, Culicoides kingi, Culicoides imicola, Culicoides enderleini and Culicoides nivosus coincide with the rainy season in September and October in Senegal [13]. Thus, Zimmer et al. [39] opined that defining the larval habitat shall be considered as essential to understanding population dynamics. Griffioen et al. [40] observed a bimodal pattern of activity, with peaks at dawn and dusk. All these observations are in the line of the present study. The highest midge activity was found around sunset, followed by a smaller peak of activity at dawn, stabling of animals at dusk and dawn might curtail the risk of disease transmission as a result of a higher activity of midges during that time of the day. However, midges are also frequently found inside stables [41] and stabling of animals will, therefore, not sufficiently protect animals from midge bites. Precise characterization of

Table-3: Culicoides collected during the year 2010 and its relationship with average weather parameters at Parbhani (Marathwada) region of Maharashtra state ${ }^{\circledR}$.

\begin{tabular}{|c|c|c|c|c|c|}
\hline Season & Month 2010 & C. peregrinus & C. schultzei & C. actoni & Total Culicoides $^{1}$ \\
\hline Monsoon* (weeks 23-44) & June & 1360 & 990 & 367 & 2730 \\
\hline \multirow{7}{*}{$4^{\text {th }}$ June- $4^{\text {th }}$ November } & July & 1698 & 1379 & 257 & 3347 \\
\hline & August & 4400 & 2460 & 518 & 7402 \\
\hline & September & 5400 & 3933 & 772 & 11020 \\
\hline & October & 2210 & 1264 & 225 & 3742 \\
\hline & Total & 15068 & 10026 & 2139 & 28241 \\
\hline & $\% *$ & 70.33 & 70.71 & 72.70 & 71.21 \\
\hline & $\% * *$ & 53.35 & 35.50 & 7.57 & \\
\hline Winter* (weeks 45-9) $5^{\text {th }}$ & November & 4280 & 2850 & 547 & 7770 \\
\hline \multirow[t]{6}{*}{ November- $4^{\text {th }}$ March } & December & 303 & 222 & 45 & 570 \\
\hline & January & 960 & 700 & 113 & 1780 \\
\hline & February & 645 & 290 & 81 & 1020 \\
\hline & Total & 6188 & 4062 & 786 & 11140 \\
\hline & $\% *$ & 28.88 & 28.65 & 26.72 & 28.08 \\
\hline & $\% * *$ & 55.54 & 36.46 & 7.06 & \\
\hline Summer* (weeks 10-22) & March & 118 & 67 & 13 & 200 \\
\hline \multirow[t]{6}{*}{$5^{\text {th }}$ March- $3^{\text {rd }}$ June } & April & 31 & 20 & 03 & 54 \\
\hline & May & 20 & 04 & 01 & 25 \\
\hline & Total & 169 & 91 & 17 & 279 \\
\hline & $\% *$ & 0.79 & 0.64 & 0.58 & 0.70 \\
\hline & $\% * *$ & 60.57 & 32.61 & 6.09 & \\
\hline & Grand total & 21425 & 14179 & 2942 & 39660 \\
\hline
\end{tabular}

*Months and weeks of a calendar year are allotted to each season according to standard meteorological norms designed for Marathwada region. Latitude $17^{\circ} 35^{\prime} \mathrm{N}-20^{\circ} 40^{\prime} \mathrm{N}$, Longitudes $70^{\circ} 40^{\prime}-78^{\circ} 15^{\prime} \mathrm{E}, \mathrm{MSL}-40.9$ m, *Percentage workout with grand total mentioned in respective column, **Percentage workout with total mentioned in the respective row. ${ }^{1}$ Total Culicoides number includes unidentified Culicoides, $@$ In each month 4 collections were made by employing light trap for 5 min and total number of Culicoides were counted. C. peregrinus=Culicoides peregrinus, C. schultzei=Culicoides schultzei, C. actoni=Culicoides actoni 
the seasonality of Culicoides midges is critical to the creation of accurate and ecologically sound parameter estimates for use in predictive models of the animal diseases transmitted by these midges and, ultimately, to the formulation of logical abatement strategies for their control [42-44]. Precise documentation of temporal changes in the annual abundance and dispersal of Culicoides midges is essential for the creation of models to predict BTV infection of livestock and to develop sound abatement strategies [45]. Thus, models need to be developed so as to better understand the influence of environmental and climatic parameters on the distribution and dynamics of Culicoides for better evaluation of the risk of diseases transmitted. In view of the importance of such models in the present study multiple regression analysis derived the important predictors of population in a particular season and predicted population equation (Table-4).

Earlier studies conducted for Marathwada region also observed the at par seasonal variation $[46,47]$. Worldwide, estimating different types of predictors related to the climatic data, many studies were undertaken and such data is used for recording peak and depression in the Culicoides population and hence at that precise time control measures can be adapted. Thompson and Connor [48] recommended the environmental information systems such as remote sensing and spatial information technologies for control of arthropod vectors. Baylis et al. [49], Baylis and Rawlings [50] used climate data and Satellite imagery model to know the abundance of Culicoides in which they estimated normalized difference vegetation index measure of photosynthetic activity and land surface temperature a measure of temperature at earth surface. These two as predictors for estimation of population peaks. Data on seasonal population dynamics not only helps to record period of peak and depression of Culicoides flies, but it also helps in forecasting the diseases transmitted by Culicoides flies as vector. Sellers [51] described the world wide weather conditions and its correlation in understanding the ecology of vector Culicoides. According to his observations Culicoides could grow in the temperature range of $10-35^{\circ} \mathrm{C}$, and they require adequate moisture. Movement of the Culicoides was found to be affected by mainly wind. In conclusion, author has highlighted two important factors in the Culicoides ecology, i.e., temperature and wind. Based on the data author correlated the weather, Culicoides distribution and spread of BTV and EHDV. After analyzing the present project data, in view of these observations, it can be concluded that in Maharashtra state and particular Marathwada region control of Culicoides midges during monsoon and winter season is important from the point of pest control and control of BT disease.

In addition to the AHSV, Culicoides also transmit BTV, EHDV, EEV, Akabane virus, bovine ephemeral fever virus and viruses in the Palyam group [5]. However, the two diseases with the greatest veterinary impact among these are BT affecting ruminants and AHS affecting equines. These two viral diseases has economic impact owing to the fact that their very broad geographical distribution and their potential for spreading rapidly and hence there is necessity of developing prediction models so as to better understand the influence of environmental and climatic parameters on the prevalence and seasonal dynamics of the vector Culicoides in a particular geographic area $[13,38]$. Ilango [9] and Ayllón et al. [52] also stressed the need of taxonomic and field biology studies on Culicoides and according to them such studies are instrumental for the implementation of control measures and disease risk analysis. Concurring to these studies, observations marked in the present study highlighted the prediction models for Culicoides population (Table-4) prevalent in the Marathwada region of Maharashtra state, will certainly help for understanding the distribution of viral diseases transmitted by Culicoides midges and for their control.

\section{Host preferences of Culicoides}

The data in Table-5 indicates the host preferences for feeding of Culicoides midges in the order of cattle, sheep, buffaloes and followed by goats. It is also clear from the data (Table-5), that species of Culicoides predominant in the region was $C$. peregrinus, however, nonetheless other two species also contributes substantially and hence in IPM programme, control measures shall be undertaken equally against all species.

Table-4: Multiple regression analysis of weather parameters and Culicoides population for the year 2010.

\begin{tabular}{llc}
\hline $\begin{array}{l}\text { Season } \\
\mathbf{( 2 0 1 0 )}\end{array}$ & $\begin{array}{l}\text { Important predictors } \\
\text { of population }\end{array}$ & Population equation \\
\hline Monsoon & $\mathrm{WV}(\mathrm{Km} / \mathrm{h})$ & $\mathrm{Y}=-22332.52+(-) 32.65 \times \mathrm{RF}+1276.34 \times \mathrm{RD}+1052.85 \times \mathrm{T}_{\min }-220.80 \times \mathrm{WV}$ \\
& $\mathrm{RF}$ in $\mathrm{mm}$ & \\
& $\mathrm{T}_{\min }$ & \\
Winter & $\mathrm{RD}$ & $\mathrm{Y}=-1466.78+1385.28 \times \mathrm{RD}+130.26 \times \mathrm{T}_{\max }-214.36 \times \mathrm{BSS}$ \\
& $\mathrm{BSS}$ & \\
& $\mathrm{T}_{\max }$ & $\mathrm{Y}=1222.33+(-87.66 \times \mathrm{BSS})+(58.33 \times \mathrm{WV})$ \\
Summer & $\mathrm{RD}$ & $\mathrm{Y}$ : Culicoides population \\
& $\mathrm{WV}(\mathrm{Km} / \mathrm{h})$, & \\
\hline
\end{tabular}

$\mathrm{WV}=$ Wind velocity, $\mathrm{RD}=$ Rainy days, $\mathrm{RF}=$ Rain fall, $\mathrm{T}_{\min }=$ Temperature minimum, $\mathrm{BSS}=$ Bright sunshine, $\mathrm{T}_{\max }=$ Temperature maximum 
Table-5: Host midge relationship of Culicoides spp. to four species of hosts in Marathwada (Parbhani) region collected during the year 2010.

\begin{tabular}{|c|c|c|c|c|c|c|c|}
\hline \multirow[t]{3}{*}{ Host } & \multicolumn{6}{|c|}{ Culicoides species } & \multirow[t]{3}{*}{ Total } \\
\hline & \multicolumn{2}{|c|}{ C. peregrinus } & \multicolumn{2}{|l|}{ C. schultzei } & \multicolumn{2}{|l|}{ C. actoni } & \\
\hline & Numbers collected & $\%$ & Numbers collected & $\%$ & Numbers collected & $\%$ & \\
\hline Cattle & 5352 & 61.66 & 2983 & 34.35 & 347 & 3.99 & 8682 \\
\hline Buffalo & 3230 & 55.61 & 2342 & 40.32 & 236 & 4.06 & 5808 \\
\hline Sheep & 3424 & 62.10 & 2022 & 36.67 & 67 & 1.21 & 5513 \\
\hline \multirow[t]{2}{*}{ Goat } & 1242 & 69.15 & 542 & 30.17 & 12 & 0.66 & 1796 \\
\hline & 13248 & 60.77 & 7889 & 36.18 & 662 & 3.03 & 21799 \\
\hline
\end{tabular}

C. peregrinus=Culicoides peregrinus, C. schultzei=Culicoides schultzei, C. actoni=Culicoides actoni

Preferential host for Culicoides is cattle, which is also a reservoir host for BTV, which is transmitted to sheep via Culicoides. Therefore, utmost care is needed to keep these two ruminant hosts at distance during the monsoon season or during the peak period of BT. In this context observations of Jones et al. [53] are pertinent to the present study. According to them, during endemic cycle of BTV, vector species do not cause a problem, but during an epizootic cycle where a midge takes blood from an infected animal, after an incubation and multiplication period, infected female transmit virus to any wild or domestic ruminant that it will feed on viz. sheep, goat, cattle, deer, antelope, etc. If a high population of midges is present, the secondary or epizootic cycle may go on repeatedly from year to year. In this context, present study on host preferences focuses mainly that Culicoides spp. had shown equal affinity to all four ruminant host species and hence it can be strongly hypothesized that species reported in this region could be possibly responsible for and for completion of circulation of BTV cycle among host species. Host preferences determine which host will be bitten and therefore be potentially infected with vectored pathogenic organisms. Host preferences of Culicoides species from Israel based on sensory organs and morphometry [54] and on the basis feeding behavior from Germany were reported by Ayllón et al. [52]. Significantly more midges were collected from cattle in the present study, indicating that cattle may be more attractive than sheep for midges, as previously suggested by other authors $[55,56]$. This has important epidemiological implications, as sheep could be a susceptible target for these vectors when cattle are absent in the vicinity. According to Ayllón et al. [52] cattle not only attract midges, but they also constitute important hosts.

\section{Conclusion}

Prevalence of C. schultzei, C. peregrinus and C. actoni was reported in the Marathwada region of Maharashtra along with other hematophagus flies viz. Phlebotomus spp. and Simulium spp. Simultaneous study undertaken by the aid of hand net, collections of fly species from Marathwada region of Maharashtra state yielded additionally, Tabanus spp., Pangonia spp., mosquitoes and other cyclorrhaphan flies. Population dynamics study on Culicoides spp. in
Marathwada region indicated that, (a) Culicoides population were persistent throughout the year; (b) two peaks of population, one in the monsoon(August-September) and another minor peak occurred during post monsoon/beginning of winter (November) of the year. Drastic reduction in the population occurred during the month of May, which is the hottest month in the year. Culicoides collections from the sheds of different host species indicated the preferences for feeding in the ascending order of preference as cattle, sheep, buffaloes and then goats.

\section{Recommendations}

The prevalence of hematophagus flies from Marathwada region of Maharashtra state necessitates the detailed studies on the epidemiology, biology and vector competence of each fly species, all being vectors of livestock diseases in different geographic areas of the country. Prediction map of the distribution of these pest species is required for to reckon risk areas.

\section{Authors' Contributions}

BWN being PI of the research project conceptualized and implemented the technical programme with the help of Junior research fellow. BWN collected, processed and analysed the data and submitted it in the form of present research article. PRS being Co-PI was involved in the finalization of technical programme and involved in validation and confirmation of data.PRS being recognised insect taxonomist, based on morphological features confirmed all insect species reported in this article. Both authors read and approved the final manuscript.

\section{Acknowledgments}

The authors are gratefully acknowledges and keep on record the gratitude toward Department of Biotechnology, Government of India, New Delhi for their valuable financial help and Dr S K Jalali from NBAII, Bangalore for species molecular identification. Acknowledgement is due to Dr V V Deshmukh PI ICAR AINP BT, Parbhani for providing data about disease in the form of map.

\section{Competing Interests}

The authors declare that they have no competing interests. 


\section{References}

1. Borkent, A. (2014) World species of biting midges (Diptera: Ceratopogonidae). Available from: http:// www.wwx.inhs.illinois.edu/files/9913/9144/3328/ CeratopogonidaeCatalog.pdf. Last accessed 18.7.2014

2. Borkent, A. (2014) The subgeneric classification of species of Culicoides - Thoughts and a warning. Available from: http://www.wwx.inhs.illinois.edu/files/9613/9136/7590/ CulicoidesSubgenera.pdf. Last accessed 18.7.2014

3. Kettle, D.S. (1977) Biology and bionomics of bloodsucking ceratopogonids. Annu. Rev. Entomol., 22: 33-51.

4. Linley, J.R., Hoch, A.L. and Pinheiro, F.P (1983) Biting midges (Diptera: Ceratopogonidae). J. Med. Entomol., 20(4): 347-364.

5. Mellor, P., Baylis, M. and Mertens, P. (2009) Bluetongue. Elsevier, Oxford, UK.

6. Hoffmann, B., Scheuch, M., Höper, D., Jungblut, R. and Holsteg, M. (2012) Novel orthobunyavirus in cattle, Europe, 2011. Emerg. Infect. Dis., 18: 469-472.

7. De Regge, N., Deblauwe, I., De Deken, R., Vantieghem, P., Madder, M., Geysen, D., Smeets, F., Losson, B., van den Berg, T., and Cay, A.B. (2012) Detection of Schmallenberg virus in different Culicoides spp. by real-time RT-PCR. Transbound. Emerg. Dis., 59(6): 471-475.

8. Hendry, G. and Godwin, G. (1988) Biting midges in Scottish forestry: A costly irritant or a trivial nuisance? Scot. Forest., 42: $113-119$

9. Ilango, K. (2006) Bluetongue virus outbreak in Tamil Nadu, Southern India: Need to study the Indian biting midge vectors, Culicoides Latreille (Diptera: Ceratopogonidae). Curr. Sci. India., 90: 163-167.

10. Conraths, F., Peters, M. and Beer, M. (2013) Schmallenberg virus, a novel orthobunyavirus infection in ruminants in Europe: Potential global impact and preventive measures. N. Z. Vet. J., 61(2): 63-67.

11. Anonymous. (1994) In: C.J. Geden., and J.A. Hogsette, editors. Proceedings of Workshop on Research and Extension Needs for Integrated Pest Management for Arthropods of Veterinary Importance. Held at Lincoln, Nebraska from April, 12-14, 1994. Available from: http://www. Cmave. usda.ufl.edu/Lincoln.html. Last accessed 15.7.2007

12. Baylis, M., el Hasnaoui, H., Bouayoune, H., Touti, J. and Mellor, P.S. (1997) The spatial and seasonal distribution of African horse sickness and its potential Culicoides vectors in Morocco. Med. Vet. Entomol., 11(3): 203-212.

13. Maryam, D., Moussa, F., Assane, G., Aliou, D., Momar, T.S., Garros, C., Balenghien, T., Allène, X., Rakotoarivony, I., Lancelot, R., Mall, I., Bakhoum, M.T., Dosum, A.M., Ndao, M., Bouyer, J. and Guis, H. (2014) Seasonal dynamics of Culicoides (Diptera: Ceratopogonidae) biting midges, potential vectors of African horse sickness and Bluetongue viruses in the Niayes area of senegal. Parasite. Vector., 7: 147.

14. Carter, H.F., Ingram, A. and Macfie, J.W.C. (1920) Observations on the Ceratopogonidae midges of the Gold coast with description of new species, part-II. Ann. Trop. Med. Parasitol., 14: 211-274.

15. Sen, P. and Dasgupta, S.K. (1959) Stdies on Indian Culicoides (Diptera: Ceratopogonidae). Ann. Entomol. Soc. Am., 52: 617-630.

16. Narladkar, B.W. (2012) In Project Report of a DBT New Delhi Financed Research Project on Development of Integrated Pest Management Module against Important Dipteran Pests of Livestock with Reference to Culicoides Midges (Diptera: Ceratopogonidae) Accepted by DBT on $4^{\text {th }}$ May, 2013.

17. Narladkar, B.W., Shastri, U.V. and Shivpuje, P.R. (1993) Studies on Culicoides spp. (Diptera: Ceratopogonidae) prevalent in Marathwada region (Maharashtra) and their host preferences. Indian Vet. J., 70(2): 116-118.

18. Foster, N.M., Jones, R.H. and McCrocy, B.R. (1963)
Preliminary investigation on insect transmission of blue tongue virus in sheep. Am. J. Vet. Res., 24: 1195-1200.

19. Luedke, A.J., Jones, R.H. and Jochim, M.M. (1967) Transmission of blue tongue between sheep and cattle by Culicoides variipennis. Am. J. Vet., Res., 28(123): 457-460.

20. Udupa, K.G. (2001) Culicoides spp (Diptera: Ceratopogonodae) associated with livestock and their relevance to blue tongue infection in Tamilnadu. Ph.D Thesis Tamilnadu Veterinary and Animal Sciences University, Chennai.

21. Bhoyar, R., Udupa, K.G., Thimmareddy, P.M., Kasralikar, V.R. and Madhav Prasad C.B. (2012) Climatological factors associated with abundance of Culicoides midges. J.Vet. Parasitol., 26:148-150.

22. Patton, W.S. (1910) Culicoides kiefferi, n. sp: A new Indian blood-sucking midge. Indian J. Med. Res., 1: 336-338.

23. Patel, P.G. (1921) Notes on the life history of Culicoides oxystoma with some remarks on the early stages of ceratopogonidae. Report $4^{\text {th }}$ Entomological Meeting, Pusa. p172-178.

24. Patton, W.S. and Evans, A.M. (1929) In: Insects, Ticks, Mites and Venomous Animals of Medical and Veterinary Importance. Part I. Medical. H.R.Grub, England. p696.

25. Smith, R.A.O. (1929) Two species of Culicoides which fed on man. Indian J. Med. Res., 17: 255-257.

26. Smith, R.A.O. and Swaminathan, C.S. (1932) Notes on some Culicoides from Assam. Indian Med. Res. Mem., 25: $182-186$

27. Sen, S.K. and Fletcher, T.B. (1962) In: Veterinary Entomology and Acarology for India. $1^{\text {st }}$ ed. Indian Council of Agricultural Research, New Delhi. p98-120.

28. Dasgupta, S.K. (1961) Studies on the incidence of some Indian Culicoides (Diptera: Ceratopogonidae). Indian Agric., 5: 189-206.

29. Dasgupta, S.K. (1962) Some Culicoides of Calcutta and the neighbouring areas. Sci. Cult., 28: 537-539.

30. Dasgupta, S.K. (1963) Report on collection of Culicoides. Bull. Entomol., 4: 38-40.

31. Dasgupa, S.K. (1963) Culicoides (Diptera: Ceratopogonidae) from suburbs of Calcutta. Entomol. Mon. Mag., 98: 253-254.

32. Dastupta, S.K. and Ghosh, S.M. (1961) Report on biting midges (Diptera: Ceratopogonidae) with additional notes on a few spp. Bull. Calcutta. Sch. Trop. Med., 9: 117-119.

33. Anantraman, M. (1965) Various aspects of protozoon, helminths and arthropod parasitism. Madras. Vet. Coll. Annu., 23: 78-79.

34. Wirth, W.W., Choudhuri, P.P. and Dasgupta, S.K. (1985) Descriptive notes and new Asian distribution in the Chaetophthalmus group of the blood sucking midge genus Culicoides (Diptera: Ceratopogonidae). Orient. Insects., 19: 103-109.

35. Narladkar, B.W. and Patil, V.G. (2012) Observations on breeding sites and seasonal dynamics of Tabanus rufofrater in Marathwada region. J. Vet. Parasitol., 26(2): 134-136.

36. Veer, V. (2004) Tabanidae flies (Diptera) from the Indian subregion. Ann. Forest., 12(2): 301-447.

37. Mitra, B., Banerjee, D. and Roy, S. (2007) A check-list of tabanid flies (Tabanidae: Diptera) of the Eastern Himalayas, India. J. Adv. Zool. 28(2): 55-66.

38. Tilibaşa, E. M. and Darabus, G. (2014) Preliminary studies on dynamics of Culicoides spp. In western Romania in conjunction with some environmental factors. Parasit. Vector., 7 Suppl 1: 07.

39. Zimmer, J.Y., Smeets, F., Simonon, G., Fagot, J., and Haubruge, E. (2013) Are bogs reservoirs for emerging disease vectors? Evaluation of Culicoides populations in the hautes fagnes nature reserve (Belgium). PLoS ONE., 8(6): e66893.

40. Griffioen, K., van Gemst, D.B., Pieterse, M.C., Jacobs, F. and Sloet van Oldruitenborgh-Oosterbaan, M.M. (2011) Culicoides species associated with sheep in the Netherlands 
and the effect of a permethrin insecticide. Vet. J. 190(2): 230-235.

41. Clausen, P.H., Stephan, A., Bartsch, S., Jandowsky, A., Hoffmann-Kohler, P., Schein, E., Mehlitz, D. and Bauer, B. (2009) Seasonal dynamics of biting midges (Diptera: Ceratopogonidae, Culicoides spp.) on dairy farms of Central Germany during the 2007/2008 epidemic of bluetongue. Parasitol. Res., 10: 381-386.

42. Szmaragd, C., Wilson, A.J., Carpenter, S., Wood, J.L. and Mellor, P.S. (2009) A modeling framework to describe the transmission of Bluetongue virus within and between farms in Great Britain. PLoS One., 4: E7741.

43. Souza Monteiro, D.M., Carrasco, L.R., Moffitt, L.J. and Cook, A.J. (2012) Robust surveillance of animal diseases: An application to the detection of bluetongue disease. Prev. Vet. Med., 105(1-3): 17-24.

44. Maclachlan, N.J. and Mayo, C.E. (2013) Potential strategies for control of Bluetongue, a globally emerging, Culicoidestransmitted viral disease of ruminant livestock and wildlife. Antivir. Res., 99(2): 79-90.

45. Mayo, C.E., Osborne, C.J., Mullens, B.A., Gerry, A.C and Gardner, I.A. (2014) Seasonal variation and impact of waste-water lagoons as larval habitat on the population dynamics of Culicoides sonorensis (Diptera: Ceratpogonidae) at two dairy farms in Northern California. PLoS One., 9(2): e89633.

46. Narladkar, B.W., Shastri, U.V. and Shivpuje, P.R. (1993) Seasonal prevalence of Culicoides spp. (Diptera: Ceratopogonidae) in Marathwada region. Indian J. Anim. Sci., 63: 1140-1145.

47. Narladkar, B.W., Deshpande, P.D., Shivpuje, P.R. and Sondge, V.D. (2006) Population dynamics of Culicoides sp of domesticated animals of Marathwada region. J. Vet. Parasitol., 20: 171-174.

48. Thompson, M.C. and Connor, S.J. (2000) Enviroment information systems for the control of arthropod vectors of disease. Med. Vet. Entomol., 14(3): 227-244.

49. Baylis, M., Bouayoune, H., Touti, J. and Hasnaouni, H.
(1998) Use of climatic data and satellite imagery to model the abundance of Culicoides imicola, the vector of African horse sickness virus, in Morocco. Med. Vet. Entomol., 12(3): 255-266.

50. Baylis, M. and Rawlings, P. (1998) Modeling the distribution and abundance of Culicoides imicola in Morocco and Iberia using climatic data and satellite imagery. In: Mellor, P.S., Baylis, M., Hablin, C. and Calisher, C.H. editors. African Horse Sickners. p137-153. (CAB Abstracts).

51. Sellers, R.F. (1991) Weather, Culicoides and the distribution and spread of Blue tongue and African horse sickness viruses. In: Watton, T.E. and Osburn, B.I., editors. Blue Tongue, African Horse Sickeness and Related Orbiviruses. Proceedings of the Second International Symposium, 17-21 June, 1991, Paris. CRC Press, Boca Raton, Florida. p284-290.

52. Ayllón, T., Ard, M.N., Wiebke, W., Burkhard, B., Xavier, A. and Peter-Henning Clausen, P.H. (2014) Feeding behaviour of Culicoides spp. (Diptera: Ceratopogonidae) on cattle and sheep in northeast Germany. Parasit. Vector., 7: 34.

53. Jones, R.H., Luedke, A.J., Walton, T.E. and Metcalf, H.E. (1981) Bluetongue in the United States; an entomological perspective toward control. World Anim. Rev., 38: 2-8.

54. Braverman, Y., Frish, K., Reis, M. and Mumcuoglu, K.Y. (2012) Host preference of Culicoides spp from Israel based on sensory organs and morphometry (Diptera: ceratopogonidae). Entomol. Gen., 34: 97-110.

55. Garros, C., Gardes, L., Allene, X., Rakotoarivony, I., Viennet, E., Rossi, S. and Balenghien, T. (2011) Adaptation of a species-specific multiplex PCR assay for the identification of blood meal source in Culicoides (Ceratopogonidae: Diptera): applications on midge species, vectors of Orbiviruses. Infect. Genet. Evol., 11(5): 1103-1110.

56. Bartsch, S., Bauer, B., Wiemann, A., Clausen, P.H. and Steuber, S. (2009) Feeding patterns of biting midges of the Culicoides obsoletus and Culicoides pulicaris groups on selected farms in Brandenburg, Germany. Parasitol. Res., 105(2): 373-380. 